How to Cite: Amerkhanova, Sh.K., Uali, A.S., Shlyapov, R.M., \& Belgibayeva, D.S. (2021). Alkali-activated metallurgical slag as a sustainable adsorbent. Bulletin of the University of Karaganda - Chemistry, 104(4), 117-127. https://doi.org/10.31489/2021Ch4/117-127

\author{
Sh.K. Amerkhanova, A.S. Uali, R.M. Shlyapov*, D.S. Belgibayeva \\ L.N. Gumilyov Eurasian National University, Nur-Sultan, Kazakhstan \\ (*Corresponding author's e-mail: rustamshlyapow@gmail.com)
}

\title{
Alkali-activated metallurgical slag as a sustainable adsorbent
}

\begin{abstract}
This paper is devoted to obtaining a zeolite-containing sorbent based on metallurgical waste - slag. The synthesis of zeolite adsorbent from ash and slag was carried out by hydrochemical and thermal treatment. The initial object and the obtained material were characterized using following methods: Fourier-transform infrared spectroscopy, scanning electron microscopy, energy dispersive analysis, X-ray phase analysis, titrimetry. The way of converting solid-phase waste into a beneficial product has been demonstrated. The study results showed that the surface of the obtained material is saturated with functional groups (hydroxy-, carboxy-, lactone), which predetermine the ability to bind metal ions during adsorption. The adsorption capacity of the product has been estimated for iodine and methylene blue. A thermodynamic analysis of the process of sorption of copper (II) ions from an aqueous solution has been conducted. It has identified that the sorbent can also be used for the adsorptive concentration of ions of rare-earth elements by the example of lanthanum and erbium. Laboratory testing of the possible use of the sorbent to purify industrial water was carried out using the example of wastewater from a chromium plating shop.
\end{abstract}

Keywords: metallurgical slag, recycling of slag, sorbents, sorption, absorption capacity, d-, f-metals ions, wastewaters purification, sorption isotherms, thermodynamics of adsorption.

\section{Introduction}

Zeolite materials are of great fundamental and industrial importance and widely used as commercial adsorbents and catalysts. All the unique properties of zeolites are specified with their structure based on porous aluminosilicates formed by a combination of tetrahedral $\left[\mathrm{SiO}_{4}\right]_{4}{ }^{-}$and $\left[\mathrm{AlO}_{4}\right]_{5}{ }^{-}$. One way to obtain them is to converse metallurgical wastes into zeolites; however, the phase composition of the material obtained by the hydrochemical pathway is controlled by various factors such as temperature, type of modifying agent and its concentration, $\mathrm{pH}$ of the media, etc. [1-5].

The purification of natural and industrial water bodies from copper ions is a significant environmental issue due to its relatively high toxicity. The threshold limit value (TLV) for copper ions in drinking and sanitary waters for domestic and industrial use is $1 \mathrm{mg} / \mathrm{L}$, then $0.001 \mathrm{mg} / \mathrm{L}$ is for reservoirs of fish economic purpose. Thus, practice shows the residual concentration of $\mathrm{Cu}$ in water purified at $\mathrm{pH}$ level from 8 to 9 is $0.1-0.2 \mathrm{mg} / \mathrm{L}$ generally, which conforms to theoretical calculations on the solubility of copper hydroxide in aqueous solutions $[6,7]$. This issue may be solved by applying sorption methods of purification with inorganic sorbents. However, even though a considerable amount of research focused on an in-depth investigation of how to turn slag into a beneficial material (in this case, adsorbent), many open questions should be answered to clarify this mechanism [7-13].

This paper aims to demonstrate the behavior of the alkali-treated metallurgical slag in the water purification by testing it for both model metal-containing solutions and in industrial multi-component water system.

\section{Experimental}

The solid-phase waste of the metallurgy plant "ArcelorMittal Temirtau" was applied as a raw material. The technique that consists of two stages is used to design the adsorbent. Firstly, the initial material has been washed with distilled water for $48 \mathrm{~h}$, then has been dried at room temperature. The ratio of $\mathrm{S} / \mathrm{L}$ was one to ten (by weight). The intermediate was treated thermally in the muffle furnace at the temperature of $600{ }^{\circ} \mathrm{C}$ for $90 \mathrm{~min}$. in the presence of sodium hydroxide solution $(2 \mathrm{~mol} / \mathrm{L})$ used as a modifying agent. The ratio of $\mathrm{S}: \mathrm{L}$ was the same. The final product has been tested for the adsorption properties.

The following methods have been applied to characterize the material synthesized: X-ray Powder Diffraction (XRD) analysis was conducted using the DRON-4-07 diffractometer. The scanning electron microscope Hitachi TM3030 with microanalysis system Bruker X Flash MINSVE (accelerating voltage of $15 \mathrm{kV}$ ) has been used to determine the elemental composition and structural features of the adsorbent. Finally, the IR-spectra of the samples have been taken by FTIR-spectrometer FSM-1201. 
The concentration of functional groups concentrated on the adsorbent's surface has been determined by the Boehm method described in [14]. In addition, the material capacity in the adsorption toward iodine and methylene blue has been estimated by well-known procedures $[15,16]$. Regarding the adsorption tests, samples of industrial multi-component waters have been taken to purify by the adsorption in a static mode at a temperature of $298 \mathrm{~K}$. The duration of this treatment was 30 minutes. The analyte's volume of each portion was $20 \mathrm{ml}$, the mass of adsorbent for each test was $0.5 \mathrm{~g}$. Both spectrophotometry and titration methods have been used to detect initial and residual concentrations of metal ions. The chemical composition of the water taken from industry has been detected by the XRF method (on the X-MET 8000 GEO portable X-ray fluorescence analyzer) before and after the adsorption tests.

The adsorption experiments with the wastewater taken from the industry were carried out at the following conditions: temperature was $293 \mathrm{~K}$, mass of each portion of the sorbent was $0.5 \mathrm{~g}$, the duration of the adsorbent/adsorbate contact was $19 \mathrm{~h}$ in the static mode. The stirring frequency with a magnetic router was $500 \mathrm{rpm}$. Three parallel series of purification experiments were performed.

\section{Results and Discussion}

It is known that the bulk of solid wastes like ashes and slags consists of both macroelements ( $\mathrm{Al}, \mathrm{Fe}$, $\mathrm{Ca}, \mathrm{Si}, \mathrm{Mg}, \mathrm{S}, \mathrm{C}$ ), which are significant constituents of mineral rocks, and microelements as minor components [17].

Experimentally (based on XRD analysis), the phase composition of the slag has included $\mathrm{Ca}_{5} \mathrm{Al}_{2}(\mathrm{OH})_{4} \mathrm{Si}_{3} \mathrm{O}_{12}, \mathrm{Fe}_{2} \mathrm{O}_{3}, \mathrm{Mg}_{3} \mathrm{Al}_{4} \mathrm{TiO}_{25}, \mathrm{MnS}$, and $\mathrm{KOH} \cdot \mathrm{H}_{2} \mathrm{O}$ that are likely to be products of the coal agglomeration. However, after the thermal treatment experienced by the slag sample, which had dried before, there was a radical change in color that turns from greyish to light blue (Fig. 1), which can be caused by phase transformations.
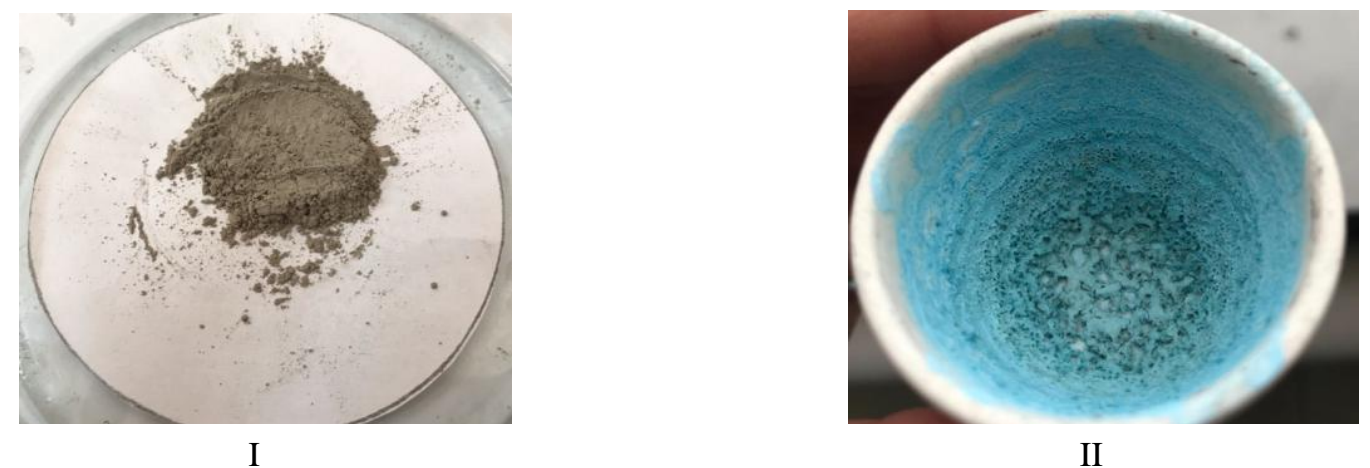

II

Figure 1. The slag dispersed of the metallurgical enterprise "Arcelor Mittal Temirtau" (I); sorbent obtained after alkaline treatment (II)

The elemental composition of the material has been determined by the energy dispersive X-Ray analysis (EDXRA) (Fig. 2, 3); the ratio of Si/Al is 20.62 approximately, which is consistent with high-silica zeolites ( $\mathrm{Si} / \mathrm{Al}$ ratio for them is from 10 to $\infty$ ) [18].

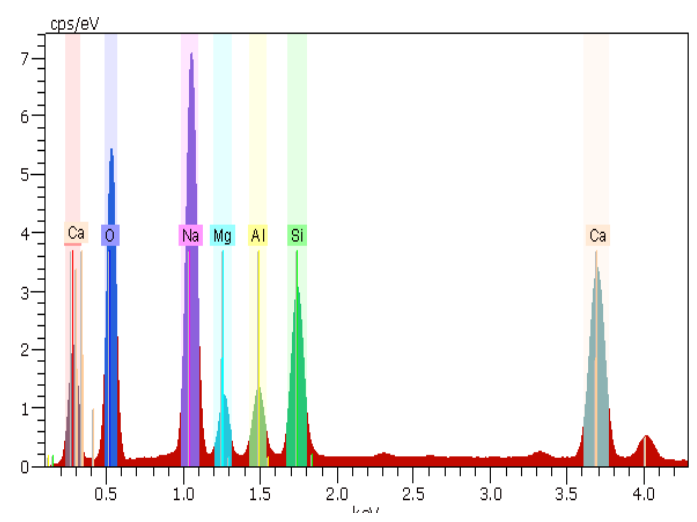

$\begin{array}{lc}\quad \text { Element } & \text { Average atomic mass, } \% \\ \text { Oxygen }(\mathrm{O}) & 51.13 \\ \text { Sodium }(\mathrm{Na}) & 16.24 \\ \text { Carbon }(\mathrm{C}) & 15.28 \\ \text { Silicon }(\mathrm{Si}) & 5.49 \\ \text { Calcium }(\mathrm{Ca}) & 6.57 \\ \text { Aluminum }(\mathrm{Al}) & 2.48 \\ \text { Magnesium }(\mathrm{Mg}) & 2.80\end{array}$

Figure 2. The EDXRA spectra and elemental composition of alkali-treated metallurgical slag 


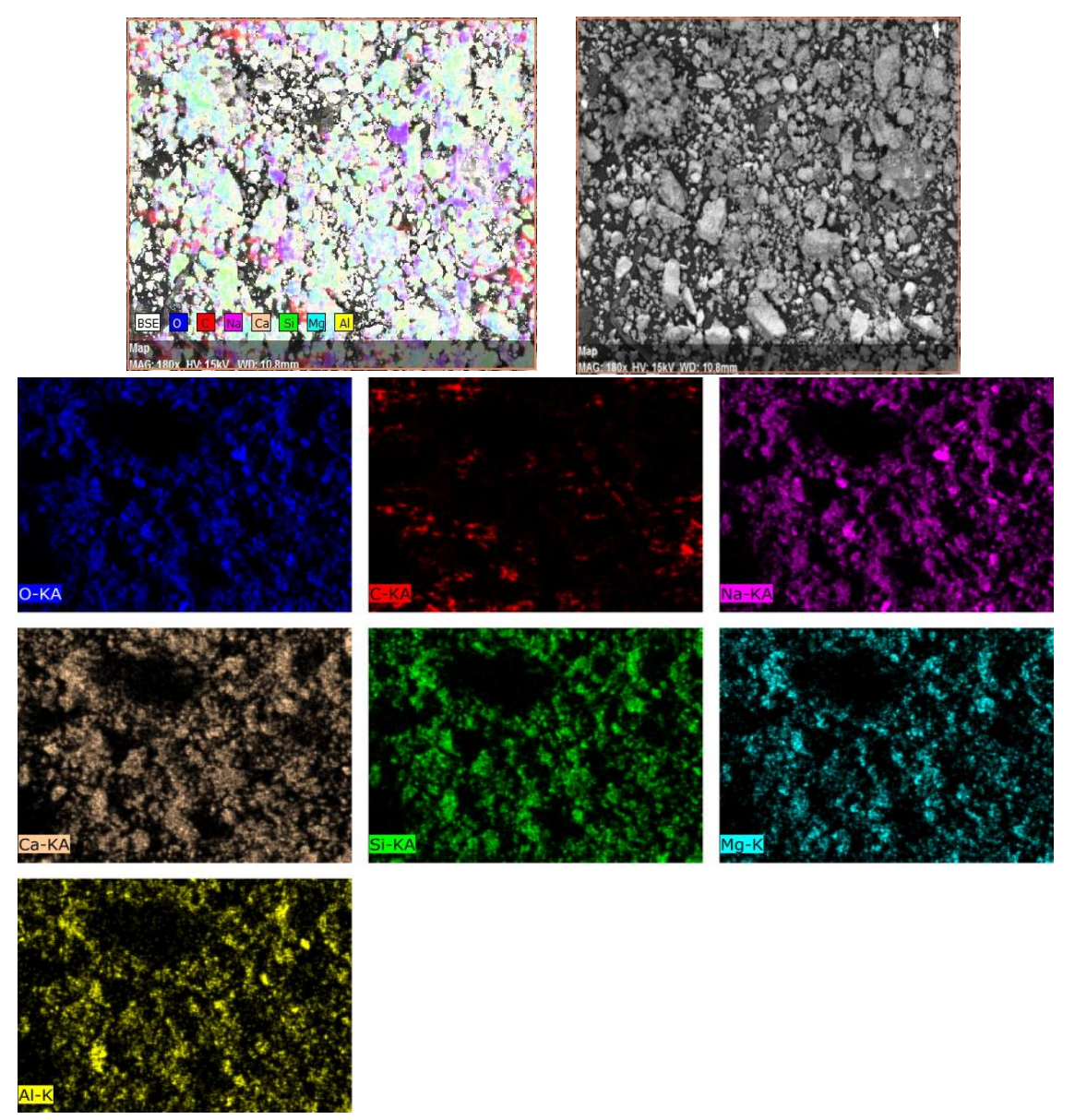

Figure 3. EDXRA pictures of alkali-treated metallurgical slag

The FTIR spectra of the studied samples can be conditionally divided into three frequency regions $<470-1600,1600-2900$, and $>2900 \mathrm{~cm}^{-1}$ (Fig. 4).

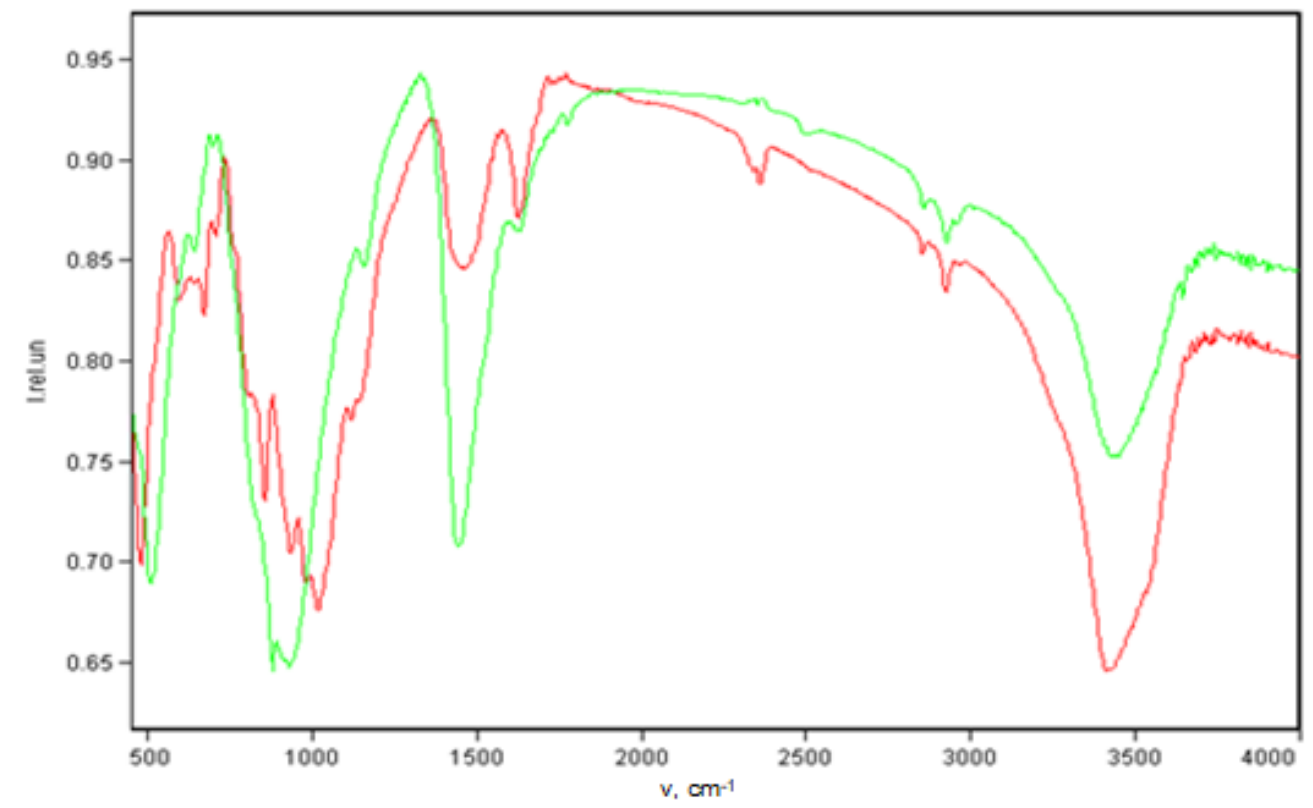

Figure 4. FT-IR spectra of the initial slag (green) and the alkali-treated sample (red)

The first region $\left(<470-1600 \mathrm{~cm}^{-1}\right)$ includes vibration bands of $\mathrm{Si}-\mathrm{O}(\mathrm{Si}), \mathrm{SO}_{4}{ }^{2-}, \mathrm{Al}-\mathrm{OH}, \mathrm{Si}-\mathrm{O}$ groups. The prominent absorption bands present in all spectra are rather intense bands at $777 \mathrm{~cm}^{-1}$. Since the Si-O 
bond is common for all silicates and clay materials, it may be assumed that the absorption bands in the region of $777-1135 \mathrm{~cm}^{-1}$ are mainly due to the stretching vibrations of Si-O.

Because of alkaline treatment, changes occur on the material surface, which are observed in the FTIR spectrum in the form of a shift of absorption bands in one direction or another. For example, the absorption band at $509 \mathrm{~cm}^{-1}$ is shifted to the left by $19 \mathrm{~cm}^{-1}$. The absorption band at $928 \mathrm{~cm}^{-1}$ has shifted to the right by $155 \mathrm{~cm}^{-1}$. The intensity of the absorption band at $1442 \mathrm{~cm}^{-1}$ due to alkaline treatment decreases by a 0.15 relative unit (a.u.).

It can be seen from the above spectra that in the second region $\left(1600-2900 \mathrm{~cm}^{-1}\right)$, the intensity of the absorption band at $2350 \mathrm{~cm}^{-1}$ as a result of alkaline treatment of the material increases by 0.05 a.u. The intensity of the absorption band at $2800-2900 \mathrm{~cm}^{-1}$ due to alkaline treatment increases by $0.02-0.03$ relative units.

The third region $>2900 \mathrm{~cm}^{-1}$ is mainly associated with the stretching vibrations of OH-groups its presence can be seen at absorption band $3435 \mathrm{~cm}^{-1}$. Absorption in the region of $3440-3738 \mathrm{~cm}^{-1}$ is presented as bands associated with vibrations of free $\mathrm{O}-\mathrm{H}$ groups. An absorption band at $3435 \mathrm{~cm}^{-1}$ increases by 0.07 a.u. in the intensity after the alkali treatment.

In addition, there is a growth in the intensity of the absorption band at $3647-3738 \mathrm{~cm}^{-1}$ by 0.04 a.u. after the treatment.

The results of the Boehm method based on acid-base titration have revealed that there are carboxyl, hydroxyl and lactone groups on the adsorbent surface (Table 1).

Ta b l e 1

Content of carboxyl-, hydroxyl and lactone functional groups in the sorbent sample

\begin{tabular}{|c|c|c|c|c|}
\hline Functional group & Total & Hydroxyl groups & Carboxyl groups & Lactone groups \\
\hline $\begin{array}{c}\text { Concentration } \\
\text { [mmole/g] }\end{array}$ & 1.06 & 0.44 & 0.30 & 0.32 \\
\hline
\end{tabular}

According to [14], the adsorbent samples were examined for the adsorption concentration of iodine and methylene blue (MB) (Table 2).

Ta b l e 2

Adsorption capacity of the sorbent synthesized toward iodine and MB

\begin{tabular}{|c|c|c|}
\hline \multirow{2}{*}{ Adsorbate } & \multicolumn{2}{|c|}{ Adsorption capacity } \\
\cline { 2 - 3 } & Carbon sorbent [17-18] & Synthesized sorbent \\
\hline Iodine X, \% & 25.00 & 13.65 \\
\hline Methylene blue A, $\mathrm{mg} / \mathrm{g}$ & 40.00 & 55.00 \\
\hline
\end{tabular}

It is found that sorbent has an adequate sorption capacity towards both substances. Nevertheless, compared to the carbon sorbent, the slag-based one works better for MB, while the former one is approximately twice efficient for iodine. Generally, it should be assumed zeolite-templated sorbent is applicable for the capture of organic and inorganic pollutants.

As for the capture of metal ions, copper was chosen for the adsorption tests. Figure 5 demonstrates the dependence of the adsorption capacity $\left(a_{e}\right)$ on $\mathrm{pH}$, and the highest $a_{e}$ values have been achieved at $\mathrm{pH} 4,6-7$.

However, these high indexes in the $\mathrm{pH}$ range 6-7 are likely to be related to the impact of hydrolysis that foster copper (II) hydroxide to form and precipitate. At $\mathrm{pH} 4$, the deprotonation of hydroxyl groups increases the number of negatively charged centers on the sorbent surface. Since a negative charge raises the electrostatic gravitational force on the surface of sorbent and metal ions, the latter ones begin to concentrate on the sorbent surface quickly. Thus, further experimental tests were carried out at pH 4.

The adsorption isotherms for the pair consisting of alkali-treated slag as adsorbent and $\mathrm{Cu}^{2+}$ ions as adsorbate (at $318 \mathrm{~K}$, under static conditions) are presented in Figure 6. 


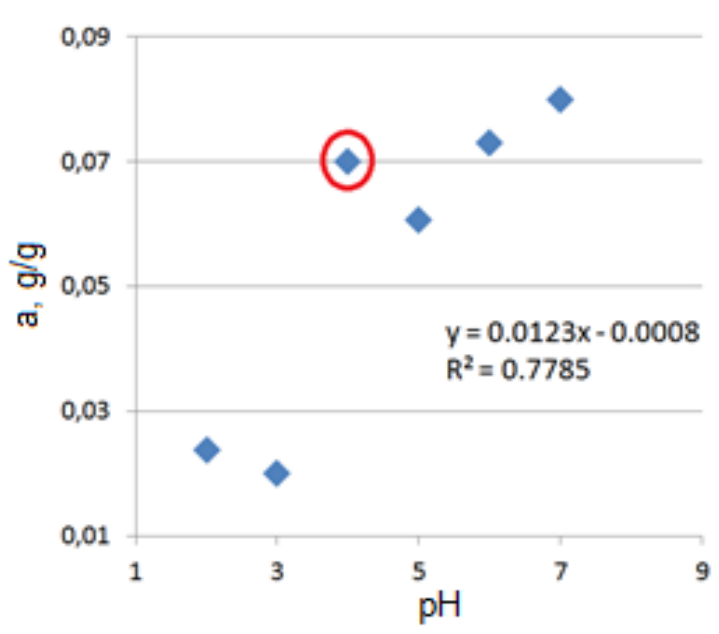

Figure 5. Effect of $\mathrm{pH}$ on the adsorption of copper (II) ions by the slag-based sorbent in aqueous solutions

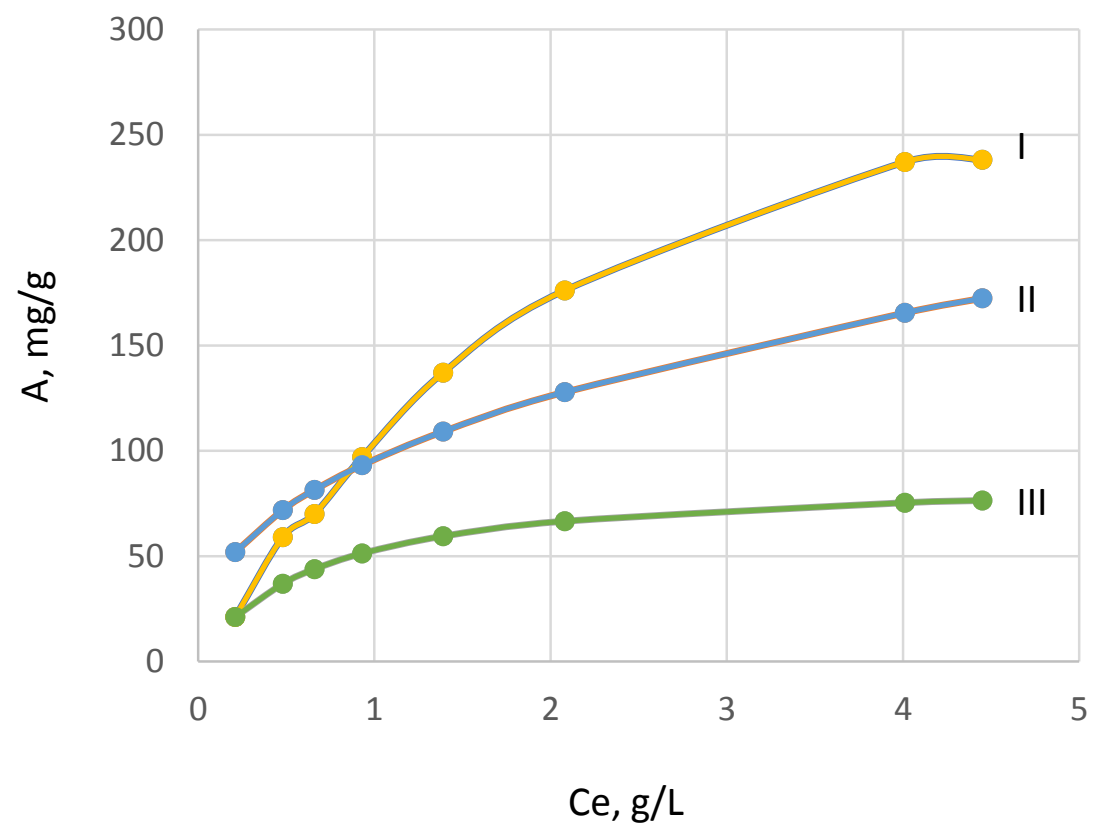

Figure 6. Adsorption isotherms $\mathrm{Cu}(\mathrm{II})$ onto sorbent at $318 \mathrm{~K}$ and $\mathrm{pH} 4$ : plotted from experimental data (I). Theoretical isotherms Freundlich (II) and Langmuir (III)

There is a level off at $4 \mathrm{~g} / \mathrm{L}$ with the degree of purification of $\approx 88.72 \%$ (Fig. 6(I)). In [19], authors have compared the adsorption capacities of copper (II) ions on various low-cost adsorbents: diatomite (27.55 $\mathrm{mg} / \mathrm{g})$ and modified diatomite $(55.56 \mathrm{mg} / \mathrm{g})$ [20], cassava waste $(56.82 \mathrm{mg} / \mathrm{g})$ [21], dehydrated wheat bran $(51.51 \mathrm{mg} / \mathrm{g})$ [22]; around low concentrations up to $1 \mathrm{~g} / \mathrm{L}$ the sorbent investigated is likely to be the alternative to them. If the metal concentration is higher than $1 \mathrm{~g} / \mathrm{L}$, the adsorbent behaviors likely the materials based on citric acid modified soybean hulls $(154.90 \mathrm{mg} / \mathrm{g})$ [23], modified orange peel (289 mg/g) [24] or nanoporous metal-organic framework MOF-5 $(290 \mathrm{mg} / \mathrm{g})$ [24].

Next, the experimental adsorption isotherm was processed using the Langmuir and Freundlich equations. By comparing the approximation coefficients and the location of isotherms on the diagram can be concluded Freundlich's model is more suitable for this case. Finally, the thermodynamic parameters that describe $\mathrm{Cu}$ (II) adsorption onto the slag-based sorbent from aqueous solutions have been calculated (Table 3). 
The adsorption constants for the Freundlich model and thermodynamic parameters of the adsorption of $\mathrm{Cu}(\mathrm{II})$ ions onto the sorbent

\begin{tabular}{|l|c|c|}
\hline \multicolumn{1}{|c|}{ Value } & $298 \mathrm{~K}$ & $318 \mathrm{~K}$ \\
\hline $1 / \mathrm{n}$ & 0.41 & 0.39 \\
\hline $\mathrm{K} \cdot 10^{-3}$ & 0.096 & 0.090 \\
\hline Correlation coefficient & 0.97 & 0.99 \\
\hline$-\Delta \mathrm{H}, \mathrm{kJ} / \mathrm{mole}$ & \multicolumn{2}{|c|}{2.29} \\
\hline$-\Delta \mathrm{G}, \mathrm{kJ} / \mathrm{mole}$ & 11.16 & 12.06 \\
\hline$\Delta \mathrm{S}, \mathrm{J} / \mathrm{mole} \cdot \mathrm{K}$ & 29.77 & 30.73 \\
\hline
\end{tabular}

The values of the isobar-isothermal potential have a negative sign that indicates the spontaneous character of the adsorption. The higher temperature is, the higher are the Gibbs energy values. The chemisorption type of adsorption can be predicted on the basis of the change in enthalpy equal to $-2.29 \mathrm{~kJ} / \mathrm{mole}$. The positive value of the change in entropy is likely to correspond to the feasibility of adsorption and the randomness that is raised at the sorbent/solution interface due to the adsorption of metal ions onto the slag-based material.

Besides that, the zeolite-templated sorbent is used to concentrate rare metals ions from aqueous solutions on the example of lanthanum (III) and erbium (III) (Table 4).

Table 4

Concentration of $\mathrm{La}^{3+}, \mathrm{Er}^{3+}$ ions on the sorbent surface

\begin{tabular}{|c|c|c|c|}
\hline Metal ions & $r_{\text {ion }}, \mathrm{pm}$ & $a, \mathrm{~mole} / \mathrm{g}$ & $\mathrm{X}, \%$ \\
\hline $\mathrm{La}^{3+}$ & 101 & $5 \cdot 10^{-4}$ & 99.80 \\
\hline $\mathrm{Er}^{3+}$ & 226 & $5 \cdot 10^{-5}$ & 99.90 \\
\hline
\end{tabular}

Thus, the results demonstrated that the level of extraction is high for both La and Er. The literature review of the $\mathrm{La}$ (III) sorption capacities of different sorbents, illustrated that though the different experimental conditions, the reported materials has comparable sorption capacities: $\mathrm{SnO}_{2}-\mathrm{TiO}_{2} \mathrm{NCs}$ nanocomposites [26] and polydopamine/nanofibrous mats [27], showing 0.473 and $0.429 \mathrm{mmole} / \mathrm{g}$, respectively. That is close to the sorbent with $0.50 \mathrm{mmole} / \mathrm{g}$ in this work (Table 4), whilst grapefruit peel has an adsorption capacity of $1.233 \mathrm{mmole} / \mathrm{g}$ [28]. As for $\mathrm{Er}(\mathrm{III})$ ions, the sorbent based on rice husk demonstrates the monolayer capacity of $250 \mathrm{mg} \cdot \mathrm{g}^{-1}$ for $\mathrm{Er}(\mathrm{III})$ [29] that is higher than the material developed has.

Regarding the purification of industrial waters, the investigated sorbent has been tested toward the wastewater that is oversaturated with metals ions from the chromium plating shop of the metallurgical plant "ArcelorMittal Temirtau". The following diagrams (Fig. 7-9) provides the results obtained by comparing the total content of metals before and after the purification (the conditions are presented in Experimental).

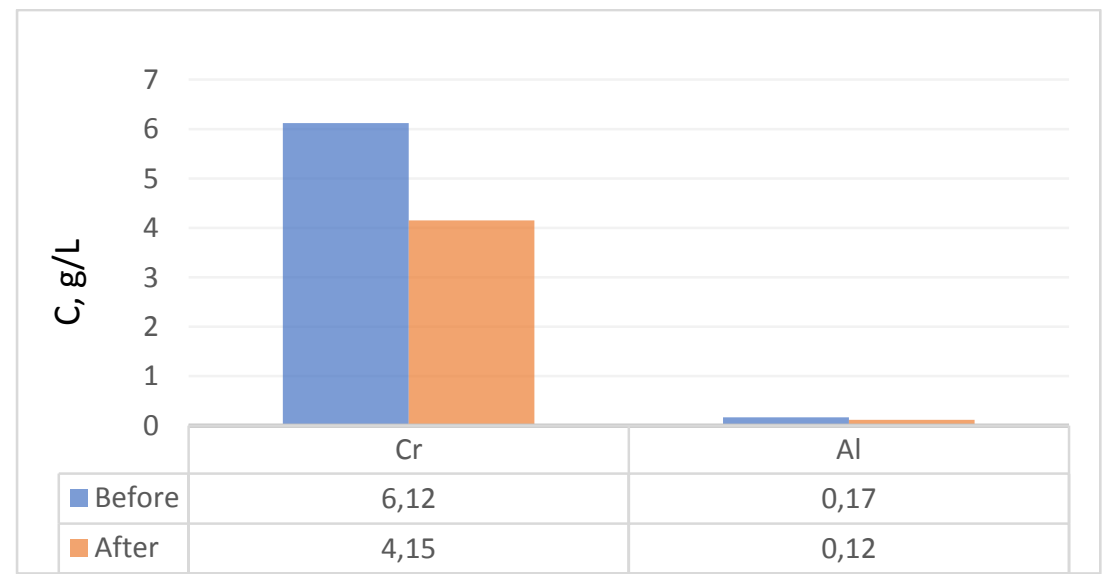

Figure 7. The change in the content of $\mathrm{Cr}$ and $\mathrm{Al}$ in the wastewater before purification and after 


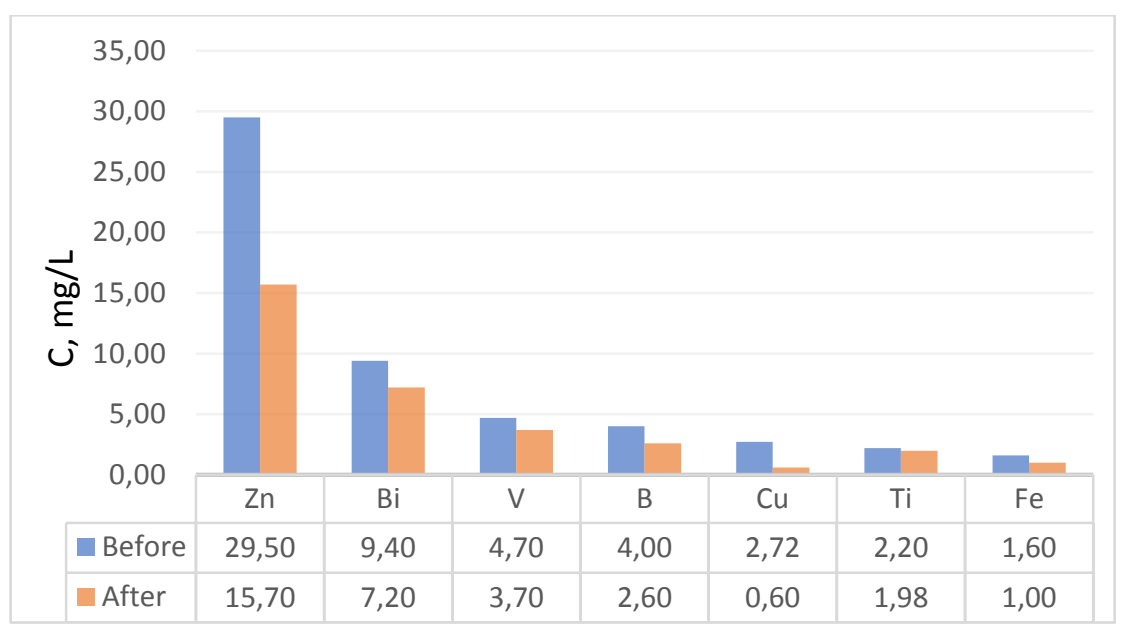

Figure 8. The change in the content of $\mathrm{Zn}, \mathrm{Bi}, \mathrm{V}, \mathrm{B}, \mathrm{Cu}, \mathrm{Ti}$, and $\mathrm{Fe}$ in the wastewater before and after purification

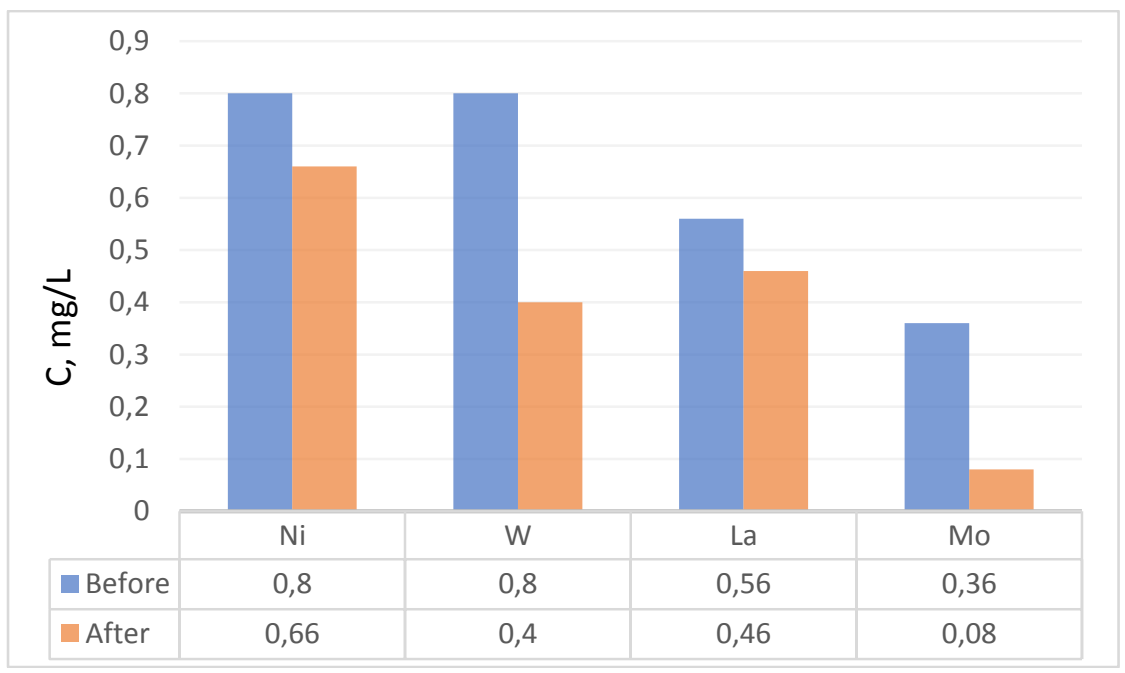

Figure 9. The change in the content of Ni, W, La, and Mo in the wastewater before and after purification

There is an overall trend of decreasing the concentrations for all metals tested. Turning to the details, the amounts of chromium and aluminon as main components have been down by 32.19 and $29.41 \%$, respectively. Likewise, the concentrations of zinc and wolfram have halved after the adsorption. As for copper and molybdenum, their amount in the wastewater has declined by four times approximately.

\section{Conclusion}

To sum up, it may be concluded that zeolite-templated adsorbent obtained by two-stage hydrochemical and thermochemical treatment from metallurgical slag has been influential in wastewater purification based on adsorption.

The possibility of using the sorbent obtained in water purification has been evaluated on the examples of model solutions that contains copper (II) ions and rare metal ions. Besides that, the adsorbent's capacity toward industrial wastewater from the metallurgical enterprise "ArcelorMittal Temirtau" has been estimated. Therefore, it can be assumed that obtained sorbent may be used in the sewage treatment.

\section{References}

1 Yong L. Synthesis and characterization of zeolite from coal fly ash / L. Yong, L. Qiong, W. Guodong, L. Xianlong, N. Ping // Journal Materials research express. - 2018. - Vol.5. — P. 1-5.

2 Худякова Л.И. Использование золошлаковых отходов тепловых электростанций / Л.И. Худякова, А.В. Залутский, П.Л. Палеев // XXI век. Техносферная безопасность. - 2019. - Т. 4, № 3. - С. 290-306. 
3 Сигачев Н.П. Эффективность использования золошлаковых отходов Забайкальского края при производстве дорожноцементных грунтов / Н.П. Сигачев, Н.А. Коновалова, В.И. Коннов, П.П. Панков, Н.С. Ефименко // Экология и промышленность России. - 2015. - Т. 19, № 1. - С. 24-27.

4 Казаков С.В. Принципы оценки радиоэкологического состояния водных объектов / С.В. Казаков // Журн. радиационной биологии России. — 2004. — Т. 44, № 6. — С. 694-700.

5 Pan M. Application of Nanosize Zeolite Molecular Sieves for Medical Oxygen Concentration/M. Pan, H.M. Omar, S. Rohani//Nanomaterials (Basel). — 2017. - Vol. 7, № 8. - P. 195.

6 Tyagi B. Separation of oxygen and nitrogen from air by molecular sieve adsorbents/ B. Tyagi, C.D. Chudasama, R. Jasra//Journal of the Indian Chemical Society. — 2001. - Vol. 78. — P. 551-563.

7 Линников О.Д. Сорбция ионов меди фильтрующим материалом АС/ О.Д. Линников, И.В. Родина, А.П. Тютюнник, Д.А. Еселевич, Л.Л. Соколова // Сорбционные и хроматографические процессы. — 2017. — Т. 17, № 1. — С. $78-86$.

8 Hutson N.D. Influence of residual water on the adsorption of atmospheric gases in Li-X zeolite: experiment and simulation / N.D. Hutson, S.C. Zajic, R.T. Yang // Industrial \& Engineering Chemistry Research. — 2002. — Vol. 39, № 6. — P. $1775-1780$.

9 Kim H. Characterization of Adsorption Enthalpy of Novel Water-Stable Zeolites and Metal-Organic Frameworks / H. Kim, H.J. Cho, Sh. Narayanan // Scientific Report. — 2016. - Vol. 6. — P. 19097.

10 Fomicheva T.I. Lignine Active Coals Used for Purification of Solutions from Inorganic Cations / T.I. Fomicheva, E.V. Koluzhnikova, J.S. Fomichev, N.G. Mihajlova // 13th International Congress Phitopharm: the book of abstracts (July, 29-31 2009). - Bonn, Germany, 2009. - P. 39.

11 Hamdi N. Removal of Phosphate Ions from Aqueous Solution Using Tunisian Clays Munerals and Synthetic Zeolite / N. Hamdi, E. Srasra // Journal of Environmental Sciences. — 2012. — Vol. 24, № 4. — P. 617-623.

12 Amerkhanova Sh.K. The active carbons modified by industrial wastes in process of sorption concentration of toxic organic compounds and heavy metals ions / Sh.K. Amerkhanova, R.M. Shlyapov, A.S. Uali // Colloids and Surfaces A: Physicochemical and Engineering Aspects. — 2017. - Vol. 532. - P. 36-40.

13 Nazarenko O. Application of Sakhaptinsk Zeolite for Improving the Quality of Ground Water / O. Nazarenko, R. Zarubina // Energy and Environmental Engineering. — 2013. - Vol. 1, № 2. - P. 68-73.

14 Boehm H.P. Chemical identification of surface groups. Advances in catalysis and related subjects. — 1966. — Vol. 16. P. 197-274.

15 ГОСТ 6217-74. (1976). Уголь активный древесный дробленый. Технические условия. МКС 71.100.40, ОКР 216239.

16 ГОСТ 21283-93 (1983). Глина бетонитовая для тонкой строительной керамики. Методы определения показателя адсорбции емкости катионного обмена.

17 Blissett R.S. A review of the multi-component utilisation of coal fly ash / R.S. Blissett, N.A. Rowson // Fuel. — 2012. Vol. 97. - P. 1-23.

18 Wang Ch. Quantitative arrangement of Si/Al ratio of natural zeolite using acid treatment / Ch. Wang, Sh. Leng, H. Guo, J. Yu, W. Li // Applied Surface Science. - 2019. — Vol. 498. - P. 143874.

19 Ojedokun At. (2015). An Overview of Low Cost Adsorbents for Copper (II) Ions Removal / At. Ojedokun, S.B. Olugbenga // J Biotechnol Biomater. — 2015. — Vol. 5(1). — P. 1000177.

20 Feng D. Removal of pollutants from acid mine wastewater using metallurgical by-product slags / D. Feng, JSJ. Van Deventer, Ch. Aldrich // Sep. Purif. Technol. — 2004. — Vol. 40(1). — P. 61-7.

21 Abia A.A. The use of chemically modified and unmodified cassava waste for the removal of $\mathrm{Cd}, \mathrm{Cu}$ and $\mathrm{Zn}$ ions from aqueous solution / A.A. Abia, M.Jr. Horsfall, O. Didi // Bioresour. Technol. — 2003. — Vol. 90. — P. 345-348.

22 Ozer A. The adsorption of copper (II) ions on to dehydrated wheat bran (DWB): determination of the equilibrium and thermodynamic parameters / A. Ozer, D. Ozer, A. Ozer // Process Biochem. — 2004. - Vol. 39. — P. 2183-2191.

23 Marshall W.E. Enhanced metal adsorption by soybean hulls modified with citric acid / W.E. Marshall, L.H. Wartelle, D.E. Boler, M.M. Johns, and C.A. Toles // Bioresour. Technol. — 1999. — Vol. 69(3). — P. 263-268.

24 Feng N. Adsorption study of copper (II) by chemically modified orange peel / N. Feng, X. Guo, S. Liang // J. Hazard. Mater. -2009. - Vol. 164(2-3). - P. 1286-1292.

25 Bakhtiari N. Adsorption of copper ion from aqueous solution by nanoporous MOF-5: A kinetic and equilibrium study / N. Bakhtiari, S. Azizian // Journal of Molecular Liquids. — 2015. — Vol. 206. — P. 114-118.

26 Rahman M.M. $\mathrm{SnO}_{2}-\mathrm{TiO}_{2}$ nanocomposites as new adsorbent for efficient removal of $\mathrm{La}$ (III) ions from aqueous solutions /M.M. Rahman, S.B. Khan, H.M. Marwani, A.M. Asiri // J. Taiwan Inst. Chem. Eng. — 2014. — Vol. 45. — P. $1964-1974$.

27 Hong G. Nanofibrous polydopamine complex membranes for adsorption of lanthanum (III) ions / G. Hong, L. Shen, M. Wang, Y. Yang, X. Zhu, M. Wang, B.S. Hsiao // Chem. Eng. J. — 2014. — Vol. 244. — P. 307-316.

28 Torab-Mostaedi M. Biosorption of lanthanum and cerium from aqueous solutions by grapefruit peel: equilibrium, kinetic and thermodynamic studies / Torab-Mostaedi, M., Asadollahzadeh, M., Hemmati, A., Khosravi, A. // Res. Chem. Intermed. — 2013. — Vol.41. - P. 559-573.

29 Awwad N.S. Sorption of lanthanum and erbium from aqueous solution by activated carbon prepared from rice husk / N.S. Awwad, H.M.H. Gad, M.I. Ahmad, H.F. Aly // Colloids and Surfaces B: Biointerfaces. — 2010. — Vol. 81(2). — P. 593-599. 
Ш.К. Амерханова, А.С. Уәли, Р.М. Шляпов, Д.С. Белгібаева

\title{
Сілтімен белсендендірілген металлургиялық қож тұрақты сорбент ретінде
}

\begin{abstract}
Мақала металлургиялық қалдықтар - шлактар негізінде цеолит бар сорбент алуға арналған. Күл мен қождан цеолит адсорбентінің синтезі гидрохимиялық және термиялық өңдеу арқылы жүргізілген. Бастапқы объект және алынған материал келесі талдау әдістерін қолдану арқылы сипатталды: ИқФурье спектроскопия, сканерлейтін электронды микроскопия, энергия дисперсиялық анализ, рентгендік фазалық талдау, титриметрия. Қатты фазалық қалдықтарды пайдалы өнімге айналдыру тәсілі берілген. Зерттеу нәтижелері көрсеткендей, алынған материалдың беті адсорбция кезінде металл иондарын байланыстыру қабілетін алдын-ала анықтайтын функционалды топтармен (гидрокси-, карбокси-, лактон) қаныққан. Өнімнің адсорбциялық қабілеті йод пен метилен көгіне қатысты бағаланады. Мыс (II) иондарының сулы ерітіндіден сорбциялану процесіне термодинамикалық талдау жасалған. Сорбентті лантан мен эрбий мысалында сирек-жер элементтерінің иондарының адсорбтивті концентрациясы үшін де қолдануға болатындығы көрсетілген. Өндірістік суды тазарту үшін сорбентті қолдану мүмкіндігінің зертханалық сынағы хромдау цехының ағынды суларының мысалында жүргізілді.
\end{abstract}

Кілт сөздер: металлургиялық қож, қожды өңдеу, сорбенттер, сорбция, сорбция қабілеті, $d$-, $f$-металл иондары, ағынды суларды тазарту, сорбциялық изотермалар, адсорбцияның термодинамикасы.

\section{Ш.К. Амерханова, А.С. Уали, Р.М. Шляпов, Д.С. Бельгибаева \\ Металлургический шлак, активированный щелочью, как устойчивый адсорбент}

\begin{abstract}
Статья посвящена получению цеолитсодержащего сорбента на основе отходов металлургического производства - шлака. Синтез цеолитного адсорбента из золошлака проводился посредством гидрохимической и термической обработки. Исходный объект и полученный материал охарактеризованы следующими методами анализа: ИК-Фурье спектроскопия, сканирующая электронная микроскопия, энергодисперсионный анализ, рентгенофазовый анализ, титриметрия. Продемонстрирован путь превращения твердофазных отходов в полезный продукт. Результаты исследования показали, что поверхность полученного материала насыщена функциональными группами (гидрокси-, карбокси-, лактоновые), предопределяющими способность связывать ионы металлов при адсорбции. Адсорбционная емкость продукта оценена по йоду и метиленовому голубому. Проведен термодинамический анализ процесса сорбции ионов меди (II) из водного раствора. Показано, что сорбент может быть использован и для адсорбционного концентрирования ионов редкоземельных элементов на примере лантана и эрбия. Кроме того, произведена лабораторная апробация возможного применения сорбента для очистки промышленных вод на примере сточной воды цеха хромирования.
\end{abstract}

Ключевые слова: металлургический шлак, переработка шлака, сорбенты, сорбция, сорбционная емкость, ионы $d$-, $f$-металлов, очистка сточных вод, изотермы сорбции, термодинамика адсорбции.

\section{References}

1 Yong, L., Qiong, L., Guodong, W., Xianlong, L. \& Ping, N. (2018). Synthesis and characterization of zeolite from coal fly ash. Journal Materials research express, 5, 1-5. https://doi.org/10.1088/2053-1591/aac3ae.

2 Khudyakova, L.I., Zalutskiy, A.V. \& Paleev, P.L. (2019). Ispolzovanie zoloshlakovykh otkhodov teplovykh elektrostantsii [Use of ash and slag waste of thermal power plants]. XXI vek. Tekhnosfernaia bezopastnot - XXI century. Technosphere Safety, 4(3), 290-306 [in Russian]. https://doi.org/10.21285/2500-1582-2019-3-375-391.

3 Sigachev, N.P., Konovalova, N.A., Konnov, V.I., Pankov, P.P. \& Yefimenko, N.S. (2015). Effektivnost ispolzovaniia zoloshlakovykh otkhodov Zabaikalskogo kraia pri proizvodstve dorozhnotsementnykh gruntov [The effectiveness of the use of the Zabaykalsky territory ash and slag waste in the production of road cement soils]. Ekologiia i promyshlennost Rossii - Ecology and Industry of Russia, 19(1), 24-27. https://doi.org/10.18412/1816-0395-2015-11-24-27 [in Russian].

4 Kazakov, S.V. (2004). Printsipy otsenki radioekologicheskogo sostoianiia vodnykh obektov [The principle of assessing the radioecological state of water bodies]. Zhurnal of Radiatsionnoi biologii Rossii - Journal Radiation biology. Radioecology, 44(6), 694-670. https://pubmed.ncbi.nlm.nih.gov/15700812 PMID: 15700812 [in Russian].

5 Pan, M., Omar, H.M. \& Rohani S. (2017). Application of Nanosize Zeolite Molecular Sieves for Medical Oxygen Concentration. Nanomaterials (Basel), 7(8), 195. https://doi.org/10.3390/nano7080195. 
6 Tyagi, B., Chudasama, C.D., Jasra, R. (2001). Separation of oxygen and nitrogen from air by molecular sieve adsorbents. Journal of the Indian Chemical Society, 78, 551-563. https://www.semanticscholar.org/paper/Separation-of-oxygen-and-nitrogenfrom-air-by-sieve-Tyagi-Chudasama/599ed12c049df8f036bd044c59fe56ca01aceb00.

7 Linnikov, O.D., Rodina, I.V., Tiutiunnik, A.P., Eselevich, D.A., \& Sokolova, L.L. (2017). Sorbtsiia ionov medi filtruiushchim materialom AS [Sorption of ions $\mathrm{Cu}^{2+}$ by filtrate material AC]. Sorbtsionnye $i$ khromatograficheskie protsessy Sorption and chromatographic processes, 17(1), 78-86. http://www.sorpchrom.vsu.ru/articles/20170110.pdf [in Russian].

8 Hutson, N.D., Zajic S.C. \& Yang R.T. (2000). Influence of residual water on the adsorption of atmospheric gases in Li-X zeolite: experiment and simulation. Industrial \& Engineering Chemistry Research, 39(6), 1775-1780. https://doi.org/10.1021/ ie990763z.

9 Kim, H., Cho, H.J., \& Narayanan, Sh., et al. (2016). Characterization of Adsorption Enthalpy of Novel Water-Stable Zeolites and Metal-Organic Frameworks. Scientific Report, 6, 19097. https://doi.org/10.1038/srep19097.

10 Fomicheva, T.I., Koluzhnikova, E.V., Fomichev, J.S., \& Mihajlova, N.G. (2009). Lignine Active Coals Used for Purification of Solutions from Inorganic Cations. 13th International Congress Phitopharm, 29-31 July 2009. (p. 39). Bonn, Germany. http://harald-g-schweim.de/phytopharm2009/0-Abstratcs.pdf.

11 Hamdi, N., \& Srasra, E. (2012). Removal of Phosphate Ions from Aqueous Solution Using Tunisian Clays Munerals and Synthetic Zeolite. Journal of Environmental Sciences, 24(4), 617-623. https://doi.org/10.1016/S1001-0742(11)60791-2.

12 Amerkhanova, Sh.K., Shlyapov, R.M., \& Uali, A.S. (2017). The active carbons modified by industrial wastes in process of sorption concentration of toxic organic compounds and heavy metals ions. Colloids and Surfaces A: Physicochemical and Engineering Aspects, 532, 36-40. https://doi.org/10.1016/j.colsurfa.2017.07.015.

13 Nazarenko, O., Zarubina, R. (2013). Application of Sakhaptinsk Zeolite for Improving the Quality of Ground Water. Energy and Environmental Engineering, 1(2), 68-73. https://doi.org/10.13189/eee.2013.010205.

14 Boehm, H.P. (1966). Chemical identification of surface groups. Advances in catalysis and related subjects, 16, $197-274$. https://jglobal.jst.go.jp/en/detail? JGLOBAL_ID=201602018030835593.

15 GOST 6217-74. (1976). Ugol aktivnyi drevesnyi droblenyi. Tekhnicheskie. usloviia [Wood crushed activated carbon. Specifications] MKS71.100.40, OKP 21 6239. Retrieved from: https://docs.cntd.ru/document/1200017213 [in Russian].

16 GOST 21283-93 (1983). Glina betonitovaia dlia tonkoi stroitelnoi keramiki. Metody opredeleniia pokazatelia adsorbtsii emkosti kationnogo obmena [Bentonite clay for fine and building ceramics. Methods for determining the adsorption index and cation exchange capacity]. Retrieved from: https://meganorm.ru/Data2/1/4294852/4294852851.pdf [in Russian].

17 Blissett, R.S., \& Rowson, N.A. (2012). A review of the multi-component utilisation of coal fly ash. Fuel, $97,1-23$. https://doi.org/10.1016/j.fuel.2012.03.024

18 Wang, Ch., Leng, Sh., Guo, H., Yu, J., \& Li, W., et al. (2019). Quantitative arrangement of Si/Al ratio of natural zeolite using acid treatment. Applied Surface Science, 498, 143874. https://doi.org/10.1016/j.apsusc.2019.143874.

19 Ojedokun, At. \& Olugbenga, S.B. (2015). An Overview of Low Cost Adsorbents for Copper (II) Ions Removal. J Biotechnol Biomater, 5(1), 1000177. http://dx.doi.org/10.4172/2155-952X.1000177.

20 Feng, D., Van Deventer, JSJ., \& Aldrich, Ch. (2004). Aldrich C. Removal of pollutants from acid mine wastewater using metallurgical by-product slags. Sep. Purif. Technol., 40(1), 61-7. http://dx.doi.org/10.1016/j.seppur.2004.01.003.

21 Abia, A.A., Horsfall, M.Jr., \& Didi, O. (2003). The use of chemically modified and unmodified cassava waste for the removal of $\mathrm{Cd}, \mathrm{Cu}$ and $\mathrm{Zn}$ ions from aqueous solution. Bioresour. Technol., 90, 345-348. https://doi.org/10.1016/S0960-8524(03)00145-7.

22 Ozer A., Ozer, D., \& Ozer, A. (2004). The adsorption of copper (II) ions on to dehydrated wheat bran (DWB): determination of the equilibrium and thermodynamic parameters. Process Biochem., 39, 2183-2191. https://doi.org/10.1016/j.procbio.2003.11.008.

23 Marshall, W.E., Wartelle, L.H., Boler, D.E., Johns, M.M. \& Toles, C.A. (1999). Enhanced metal adsorption by soybean hulls modified with citric acid. Bioresour. Technol., 69(3), 263-268. https://doi.org/10.1016/S0960-8524(98)00185-0.

24 Feng, N., Guo, X., \& Liang, S. (2009). Adsorption study of copper (II) by chemically modified orange peel. J. Hazard. Mater., 164(2-3), 1286-1292. https://doi.org/10.1016/j.jhazmat.2008.09.096.

25 Bakhtiari, N., \& Azizian, S. (2015). Adsorption of copper ion from aqueous solution by nanoporous MOF-5: A kinetic and equilibrium study. Journal of Molecular Liquids, 206, 114-118. https://doi.org/10.1016/j.molliq.2015.02.009.

26 Rahman, M.M., Khan, S.B., Marwani H.M., \& Asiri, A.M. (2014). $\mathrm{SnO}_{2}-\mathrm{TiO}_{2}$ nanocomposites as new adsorbent for efficient removal of $\mathrm{La}(\mathrm{III})$ ions from aqueous solutions. J. Taiwan Inst. Chem. Eng., 45, 1964-1974. http://dx.doi.org/10.1016/ j.jtice.2014.03.018.

27 Hong, G., Shen, L., Wang, M., Yang, Y., Wang, X., Zhu, M., \& Hsiao, B.S. (2014). Nanofibrous polydopamine complex membranes for adsorption of lanthanum (III) ions. Chem. Eng. J., 244, 307-316. https://doi.org/10.1016/j.cej.2014.01.073.

28 Torab-Mostaedi, M., Asadollahzadeh, M., Hemmati, A., \& Khosravi, A. (2013). Biosorption of lanthanum and cerium from aqueous solutions by grapefruit peel: equilibrium, kinetic and thermodynamic studies. Res. Chem. Intermed., 41, $559-573$. http://dx.doi.org/10.1007/s11164-013-1210-4.

29 Awwad, N.S., Gad, H.M.H., Ahmad, M.I., \& Aly, H.F. (2010). Sorption of lanthanum and erbium from aqueous solution by activated carbon prepared from rice husk. Colloids and Surfaces B: Biointerfaces., 81(2), 593-599. https://doi.org/10.1016/j.colsurfb.2010.08.002. 


\section{Information about authors}

Amerkhanova Shamshiya Kenzhegazinovna - Doctor of chemical sciences, Professor, L.N. Gumilyov Eurasian National University, Kazhymukan street, 13, 010000, Nur-Sultan, Kazakhstan, e-mail: amerkhanovashk@gmail.com; https://orcid.org/0000-0002-2492-4203;

Uali Aitolkyn Sailaubekkyzy - Candidate of chemical sciences, Associate Professor, L.N. Gumilyov Eurasian National University, Kazhymukan street, 13, 010000, Nur-Sultan, Kazakhstan, e-mail: ualiaitolkyn@gmail.com; https://orcid.org/0000-0002-5851-6566;

Shlyapov Rustam Maratovich (corresponding author) - Candidate of chemical sciences, Associate Professor, L.N. Gumilyov Eurasian National University, Kazhymukan street, 13, 010000, Nur-Sultan, Kazakhstan, e-mail: rustamshlyapow@ gmail.com; https://orcid.org/0000-0003-0696-214X;

Belgibayeva Dana Sapargalievna - Candidate of chemical sciences, L.N. Gumilyov Eurasian National University, Kazhymukan street, 13, 010000, Nur-Sultan, Kazakhstan, e-mail: dana0577.77@gmail.com; https://orcid.org/0000-0002-4225-600X 